\title{
PENGARUH PERANAN DAN POLA ASUH ORANG TUA TERHADAP HASIL BELAJAR SISWA SEKOLAH DASAR NEGERI (SDN) DI KECAMATAN BOGOR BARAT
}

\author{
Wulan Ratna Ningrum \\ SD Negeri Kabupaten Bogor \\ e-mail: wulanratna81@gmail.com
}

\begin{abstract}
The aims of the study is to analyze the partial and simultaneous influence of parent role and parenting patterns on students learning achievement at Elementary Public School (Sekolah Dasar Negeri) in the District of West Bogor. A survey was conducted by distributing questionnaires to the respondents, complemented with interview for qualitative data. Student achievement is collected as part of the research data. The respondents are 100 parents from 50 schools throughout the district. The results of the study reveals that there is a positive and significant partial influence of parent role and parenting pattern on student learning achievement. Parent role and parenting pattern also have positive and significant simultaneous effect on student learning achievement. It can be concluded that efforts to improve student learning achievement should take into account parent role and parenting patterns.
\end{abstract}

Keywords: parent role, parenting patterns, learning achievement

\begin{abstract}
ABSTRAK
Tujuan dari penelitian ini adalah untuk menganalisis pengaruh parsial dan simultan peran orangtua dan pola pengasuhan terhadap prestasi belajar siswa di Sekolah Dasar Negeri di Kabupaten Bogor Barat. Pengumpulan data dilakukan melalui survei dengan menyebarkan kuesioner kepada responden, dilengkapi dengan wawancara untuk data kualitatif. Prestasi siswa dikumpulkan sebagai bagian dari data penelitian. Responden penelitian adalah 100 orang tua dari 50 sekolah di seluruh kabupaten. Hasil penelitian menunjukkan bahwa terdapat pengaruh parsial yang positif dan signifikan peran orangtua dan pola pengasuhan terhadap prestasi belajar siswa. Peran orang tua dan pola pengasuhan secara simultan juga berpengaruh positif dan signifikan terhadap prestasi belajar siswa. Dengan demikian dapat disimpulkan bahwa upaya peningkatan prestasi belajar siswa harus memperhatikan peran orang tua dan pola pengasuhan siswa oleh orang tua di rumah.
\end{abstract}

Kata kunci: peranan orang tua, pola pengasuhan, hasil belajar siswa

Pendidikan di dalam keluarga merupakan pendidikan kodrati, setelah anak lahir. Pengenalan dalam keluarga antara orang tua dan anak-anaknya akan diliputi rasa cinta kasih, ketentraman dan kedamaian sehingga anak-anak akan tumbuh dan berkembang ke arah kedewasaan dengan wajar. Pendidikan menurut Purwanto (2002:1) adalah segala usaha yang dilakukan oleh orang dewasa untuk memimpin perkembangan jasmani dan rohani anak-anak dalam pergaulannya ke arah 
kedewasaan. Menurut Hadi (2003:22) orang tua adalah ayah dan ibu yang menjadi pendidik utama bagi anak-anaknya. Orang tua sebagai pendidik kodrati. Sebagai orang tua berkewajiban mendidik, mengasuh dan membesarkan anaknya. Orang tua pasti menginginkan anaknya menjadi anak yang baik, berbakti, dan mempunyai masa depan yang cerah, karena itu orang tua memegang peranan yang sangat penting dalam membimbing, mendampingi anak dalam kehidupan keseharian anak serta menjadi teladan bagi anaknya. Orang tua memiliki kewajiban untuk menciptakan lingkungan yang kondusif sehingga dapat mengembangkan potensi anak, kecerdasan dan rasa percaya diri. Selain itu, orang tua harus memahami setiap tahap perkembangan anak serta kebutuhan pengembangan kecerdasan anak dari setiap tahap. Pada saat anak masih kecil, orang tua mengajarkan banyak hal sebagai dasar pembentukan perilaku.

Setelah anak menginjak usia remaja, orang tua harus mengawasi dan mengarahkan dengan siapa anak bergaul agar anak tidak terjerumus dalam pergaulan bebas dan kenakalan remaja. orang tua harus membimbing dan mengarahkan anak agar anak dapat menilai mana perbuatan yang baik dan tidak baik, serta mana yang boleh dan tidak boleh dilakukan, karena itu sejak dini dalam pendidikan keluarga dalam diri anak perlu ditanamkan nilai, moral dan keyakinan agama sebagai dasar berperilaku. Keluarga sebagai kelompok masyarakat terkecil terbentuk oleh ikatan dua orang dewasa yang berlainan jenis kelamin, pria dan wanita serta anak-anak yang mereka lahirkan. Dari beberapa fungsi keluarga, salah satunya adalah memberikan pendidikan terbaik, yakni pendidikan yang mencakup pengembangan potensi-potensi yang dimiliki oleh anak-anak yaitu potensi nalar, fisik dan nurani atau kalbu, maka keluarga yang baik di dalamnya akan terjadi interaksi diantara para anggotanya.

Prestasi belajar dipengaruhi oleh banyak faktor baik dari dalam dan luar diri siswa. Slameto (2010: 54-60) berpendapat bahwa yang dimaksudkan dengan faktor internal adalah faktor yang berasal dari dalam diri siswa, seperti disiplin belajar, kondisi fisiologis (keadaan fisik siswa), kondisi psikologi (kecerdasan, bakat, minat, motivasi), sedangkan faktor eksternal adalah faktor yang berasal dari luar diri siswa, seperti faktor lingkungan, keluarga, (kurikulum, sarana dan prasarana serta pendidik).

Faktor yang berasal dari luar diri siswa yang memengaruhi hasil belajar siswa adalah lingkungan keluarga. Keluarga memiliki peranan penting dalam hal pengajaran dan perlindungan anak, dari mulai anak lahir sampai dengan masa remaja. Menurut Chasiyah, dkk (2009:81) fungsi dasar keluarga adalah memberi rasa memiliki, rasa aman, kasih sayang dan mengembangkan hubungan yang baik diantara anggota keluarga. Anak merupakan tanggung jawab orang tua, maka dari itu orang tua harus berusaha untuk memberikan yang terbaik untuk anak-anak mereka. Keluarga memiliki peranan yang sangat penting dalam pendidikan anak, karena keluarga, terutama orang tua, adalah lingkungan serta orang yang pertama tama dikenal oleh anak. Dengan demikian pendidikan dasar sejatinya merupakan tanggung jawab orang tua.

Menurut Faizi (2012:11) orang tua adalah orang yang paling bertanggungjawab terhadap masa depan anak-anak mereka. Orang tua lah yang melahirkan, merawat, membiayai, dan terlebih lagi mendidik anak-anak mereka. Lebih lengkapnya, Verkuyl dalam Ahmadi (2007:227) mengemukakan bahwa tugas dan panggilan orang tua yang pertama adalah mengurus keperluan materi anak seperti memberi makan, tempat perlindungan, dan pakaian kepada anak. Yang kedua adalah menciptakan suatu "home" untuk anak yang berarti anak dapat berkembang subur dalam keluarga, merasakan kemesraan dan kasih sayang. Kemudian yang ketiga adalah memberikan pendidikan yang merupakan tugas terpenting orang tua terhadap anak-anaknya. Menurut Lestari 
(2012:153) peranan orang tua adalah cara-cara yang digunakan oleh orang tua terkait erat dengan pandangan orang tua mengenai tugas-tugas yang mesti dijalankan dalam mengasuh anak.

Pola asuh atau pola pengasuhan secara umum dimaknai sebagai cara orangtua memperlakukan anak dalam berbagai hal, baik dalam berkomunikasi, mendisiplin, memonitor, mendorong atau memberi semangat, dan sebagainya. Menurut Glasgow dalam Slicker (2005), pola asuh merupakan sekumpulan sikap, kebiasaan dan ekspresi non verbal orangtua yang memberi ciri pada sifat interaksi anak dan orangtua dalam menghadapi berbagai situasi.

Hasil ulangan mata pelajaran Pendidikan Kewarganegaraan (PKn) dari 180 siswa kelas 5 Sekolah Dasar Negeri (SDN) di Kecamatan Bogor Barat yang diambil dari 8 gugus dimana masingmasing gugus diambil sebanyak 10 siswa, diketahui bahwa hasil belajar PKn sebagian siswa di SDN di Kecamatan Bogor Barat belum menunjukkan hasil yang maksimal. Diduga hal ini terjadi karena kurangnya aktivitas siswa dalam belajar, tetapi kemungkinan juga disebabkan pola asuh dari orang tua dan peranan orang tua dalam proses belajar anak.

\section{Kajian Pustaka}

Hasil belajar

Hasil belajar dapat diartikan sebagai hasil yang dicapai oleh individu setelah mengalami suatu proses belajar dalam jangka waktu tertentu. Hasil belajar juga diartikan sebagai kemampuan maksimal yang dicapai seseorang dalam suatu usaha yang menghasilkan pengetahuan atau nilainilai kecakapan. Lebih lanjut Nurkancana dan Sunartana mengemukakan bahwa hasil belajar bisa juga disebut kecakapan aktual (actual ability) yang diperoleh seseorang setelah belajar, suatu kecakapan potensial (potensial ability) yaitu kemampuan dasar yang berupa disposisi yang dimiliki oleh individu untuk mencapai prestasi. Kecakapan aktual dan kecakapan potensial ini dapat dimasukkan ke dalam suatu istilah yang lebih umum yaitu kemampuan (ability).

Hasil belajar dapat diartikan sebagai hasil yang dicapai oleh peserta didik setelah peserta didik yang bersangkutan dimaksudkan dalam penelitian ini adalah kecakapan nyata (actual) bukan kecakapan potensial. Prestasi peserta didik dipengaruhi oleh faktor dalam diri peserta didik yang meliputi IQ, motivasi, minat, bakat, kesehatan dan faktor luar peserta didik, yang meliputi misalnya guru, materi ajar, latihan, sarana kelengkapan belajar, lokasi belajar di sekolah atau di rumah.

Hasil belajar merupakan hal yang tidak dapat dipisahkan dari kegiatan belajar, karena kegiatan belajar merupakan proses, sedangkan prestasi merupakan hasil dari proses belajar. Memahami pengertian hasil belajar secara garis besar harus bertitik tolak kepada pengertian belajar itu sendiri. Hasil belajar merupakan perwujudan perilaku belajar yang biasanya terlihat dalam perubahan, kebiasaan, keterampilan, sikap, pengamatan dan kemampuan. Hasil belajar dapat dilihat dan diukur.

Dari berbagai pendapat di atas dapat dikatakan bahwa hasil belajar adalah suatu pola perbuatan, tindakan, nilai, sikap, apresiasi dan keterampilan yang didapatkan oleh para peserta didik melalui suatu proses belajar, yang mencakup kemampuan kognitif, afektif, dan juga psikomotorik. Secara nyata hasil belajar dapat berupa skor atau nilai setelah mengerjakan suatu tes. Tes yang digunakan untuk mengukur Hasil belajar merupakan suatu alat untuk mengukur aspek-aspek tertentu dari peserta didik misalnya pengetahuan, pemahaman atau aplikasi suatu konsep. (Djamarah, 2010).

Pendidikan Kewarganegaraan (PKn) adalah wahana untuk mengembangkan dan melestarikan nilai luhur dan moral yang berakar pada budaya bangsa Indonesia yang diharapkan dapat diwujudkan dalam bentuk perilaku dalam kehidupan sehari-hari peserta didik, baik sebagai 
individu maupun sebagai anggota masyarakat, warga negara, dan makhluk ciptaan Tuhan Yang Maha Esa.

\section{Pendidikan Kewarganegaraan (PKn)}

Tujuan Pendidikan Kewarganegaraan (PKn) secara umum, harus disesuaikan dengan keberhasilan pencapaian pendidikan nasional yaitu: "Mencerdaskan kehidupan bangsa, mengembangkan manusia Indonesia seutuhnya, yaitu manusia yang beriman dan bertaqwa kepada Tuhan Yang Maha Esa dan berbudi pekerti luhur, memiliki pengetahuan dan keterampilan, kesehatan jasmani dan rohani, berkepribadian mantap dan mandiri serta bertanggung jawab kemasyarakatan. (UU RI No.20 Tahun 2003).

Pencapaian tujuan pembelajaran yang mulia ini ditunjukkan oleh kemampuan berpikir kritis dan perilaku peserta didik. Oleh sebab itu pembelajaran materi PKn harus dioperasionalkan melalui tujuan kurikulum serta sosok program dan pola pengajaran PKn. Dalam penelitian ini hasil belajar siswa ditunjukkan melalui nilai PKn dari rapor siswa.

\section{Peran orang tua}

Menurut Atmosiswoyo dan Subyakto (2012:116) yang dimaksudkan dengan peranan orang tua adalah bagaimana keluarga membentuk perilaku generasi berikut sesuai dengan norma dan nilai yang baik dan sesuai dengan kehidupan masyarakat. Iryanto (2000:201) memeberi penekanan pada unsur keikutsertaan atau keterlibatan. Dengan demikian seseorang dikatakan berperan apabila orang itu ikut serta atau terlibat dalam suatu kegiatan. Peranan dalam bentuk keterlibatan orangtua sangat membantu perkembangan belajar anak, bahkan ditegaskan oleh Hamalik (2005:15) bahwa orangtua turut bertanggungjawab atas kemajuan belajar anak-anaknya.

Pemenuhan kebutuhan anak tidak cukup dalam bentuk materi, tetapi orangtua perlu memenuhi kebutuhan belajar anak secara psikis, seperti memberikan pujian, menegur, mengawasi, turut serta dan aktif dalam program kegiatan sekolah. Dengan kata lain, peranan orangtua adalah suatu proses keikutsertaan orangtua kepada dalam proses belajar anak, memberi bimbingan, memahami dan membantu mengatasi kesulitan belajar anak, serta membantu mengembangkan potensi anak secara optimal.

\section{Pola asuh}

Singgih (2007:109) berpendapat bahwa pola asuh orang tua adalah sikap dan cara orang tua dalam mempersiapkan anggota keluarga yang lebih muda termasuk anak untuk dapat mengambil keputusan dan bertindak sendiri sehingga mengalami perkembangan dari ketergantungan kepada orang tua menjadi bertanggungjawab secara mandiri. Pola asuh secara umum diarahkan pada cara orangtua memperlakukan anak dalam berbagai hal, baik dalam berkomunikasi, mendisiplinkan, memonitor, mendorong dan sebagainya. Menurut Glasgow dalam Slicker (2005), pola asuh merupakan sekumpulan sikap, kebiasaan dan ekspresi non verbal orangtua yang memberi ciripada sifat interaksi anak dan orangtua dalam menghadapi berbagai situasi.

Melalui beberapa pendapat yang telah dikemukakan di atas, maka dapat disimpulkan bahwa pola asuh orang tua merupakan pola pengasuhan orang tua terhadap anak, bagaimana orang tua memperlakukan anak, mendidik, membimbing dan mendisiplin serta melindungi anak dalam mencapai proses kedewasaan, berperilaku sesuai dengan norma dan nilai yang baik dalam kehidupan masyarakat. 
Dalam penelitian ini pola asuh orang tua dikembangkan dalam dua dimensi, yaitu dimensi 'tuntutan' dan 'tanggapan'. Dimensi tuntutan atau demandingness, ditunjukan oleh indikator: (a) memberikan batasan terhadap aktivitas anak, (b) menuntut sikap tanggung jawab anak, (c) memberikan peraturan yang harus ditaati oleh anak, (d) terlibat dalam kehidupan anak, dan (e) memberikan ganjaran secara continue. Dimensi tanggapan atau responsiveness ditunjukkan dengan indikator: (a) perhatian terhadap anak, (b) respon terhadap kebutuhan anak, (c) meluangkan waktu dan melakukan kegiatan bersama anak, (d) kepekaan terhadap emosi anak, dan (e) memberikan penghargaan terhadap prestasi dan perilaku positif anak.

\section{METODE}

Penelitian ini menggunakan metode survei dengan menyebarkan kuesioner dan melakukan wawancara dengan responden. Responden dalam penelitian ini adalah orang tua dari siswa kelas 5 SDN di Kecamatan Bogor Barat, sebanyak 100 orang, dari populasi sebanyak 3003 orang tua. Adapun kriteria penentuan sampel yang digunakan adalah orang tua yang anaknya memiliki nilai rapor PKn antara nilai 60 sampai dengan 90. Penentuan siswa yang menjadi responden ditentukan oleh guru kelas/siswa yang bersangkutan. Sampel dalam penelitian ini dapat ditentukan dengan teknik simple random sampling didasarkan dari pendapat Arikunto (2010:134-185) sampel adalah sebagian atau wakil populasi yang diteliti.

Berdasarkan pengertian di atas, dapat disimpulkan bahwa sampel adalah bagian populasi yang hendak diteliti dan mewakili karaketristik populasi. Apabila populasi penelitian berjumlah kurang dari 100 maka sampel yang diambil adalah semuanya, namun apabila populasi penelitian berjumlah lebih dari 100 maka sampel dapat diambil antara $10-15 \%$ atau $20-25 \%$ atau lebih. Dalam penelitian dipilih sampel dari kelompok-kelompok unit yang kecil. Kemudian dipilih secara acak sebagai wakil dari populasi, kemudian seluruh elemen terpilih dijadikan sebagai sampel penelitian. Sampel dalam penelitian ini adalah sebanyak 100 orang. 100 orang responden diambil dari orang tua seluruh SDN di Kecamatan Bogor Barat, Kota Bogor adalah sebanyak 50 SDN, sehingga terdapat 2 orang tua siswa yang menjadi responden.

Orang tua dari siswa yang terpilih menjadi responden, maka terpilih menjadi responden juga. Dalam penelitian ini untuk menentukan responden peneliti meminta bantuan guru. Teknik pengambilan sampel dalam penelitian pada siswa SDN di Kecamatan Bogor Barat yaitu dilakukan dengan memilih masing-masing SD 2 orang responden (orang tua dari siswa untuk masing-masing sekolah) dalam hal ini guru memilih secara acak dari daftar siswa yang ada di sekolah masingmasing dengan cara diundi, dimana nama siswa yang keluar dari proses pengundian, maka orangtuanya dijadikan responden.

Metode pengumpulan data dilakukan dengan data primer berupa kuesioner yang dibagikan kepada orang tua siswa yang berjumlah 100 orang dan nilai raport mata pelajaran PKn siswa. Hal ini dilakukan untuk memperoleh tanggapan mengenai variabel peranan dan pola asuh orang tua dengan Hasil Belajar PKn siswa SDN di Kecamatan Bogor Barat. Pengumpulan data dilakukan dengan alat bantu kuesioner.

Kuesioner yang diisi oleh responden dibuat dalam bentuk pertanyaan tertutup, artinya dalam kuesioner sudah ditentukan alternatif jawaban dari tiap item pertanyaan. Dalam pelaksanaan pengisian kuesioner, responden diperintahkan untuk memilih satu jawaban yang sekiranya cocok dengan keadaan yang dialaminya. Dalam penelitian ini, peneliti akan menggunakan yakni skala Likert. Menurut Sekaran (2006:32), skala Likert dibagi menjadi 5 dari nilai tertinggi sampai dengan nilai yang terendah yaitu Sangat Tidak Setuju $(S T S)=1$; Tidak Setuju $(T S)=2$; Netral $(N)=3$; Setuju 
$(S)=4$; Sangat Setuju $(S S)=5$. Analisis ini digunakan untuk mengukur pengaruh variabel independen pendidikan formal dan perhatian orang tua dengan.

Hasil Belajar PKn siswa SDN di Kecamatan Bogor Barat, diolah dengan menggunakan SPSS 22.0 dengan level signifikan 5\%, dan dianalisis menggunakan persamaan regresi berganda. Uji F (Pengujian secara serempak) digunakan untuk mengetahui apakah secara bersama-sama variabel independen berpengaruh terhadap variabel dependen. Uji $\mathrm{R}$ digunakan untuk mengetahui berapa \% variasi variabel dependen atau terikat dapat dijelaskan oleh variasi variabel independen atau bebas, sedangkan sisanya dijelaskan oleh variabel lain di luar model.

\section{HASIL PENELITIAN}

Dari analisis parsial diketahui bahwa terdapat pengaruh peranan orang tua terhadap Hasil Belajar PKn siswa, yang lebih besar dibandingkan dengan pengaruh peranan orang tua terhadap hasil belajar PKn siswa.

Tabel 1. Pengaruh Partial Peranan Orang Tua dan Pola Asuh Pada Hasil Belajar Coefficients $^{a}$

\begin{tabular}{lcrccc}
\hline \multirow{2}{*}{ Model } & \multicolumn{2}{c}{ Unstandardized Coefficients } & $\begin{array}{c}\text { Standardized } \\
\text { Coefficients }\end{array}$ & \multirow{2}{*}{$t$} & Sig. \\
\cline { 2 - 4 } & \multicolumn{1}{c}{ B } & Std. Error & Beta & & \\
\hline (Constant) & 6,462 & 3,579 & & 1,805 & 0,074 \\
Peranan Orang Tua & 0,656 & 0,076 & 0,680 & 8,640 & 0,000 \\
Pola Asuh & 0,229 & 0,072 & 0,248 & 3,158 & 0,002 \\
\hline
\end{tabular}

a. Dependent Variable: Hasil Belajar Siswa

Pengaruh positif dan signifikan peranan orang tua terhadap Hasil Belajar PKn siswa ditunjukkan oleh nilai Beta 0,656 dengan tingkat signifikansi $0,000<0,05$. Pengaruh positif dan signifikan pola asuh orang tua terhadap hasil belajar PKn siswa ditunjukkan oleh nilai Beta 0,248 dan tingkat signifikansi $0,000<0,05$. Dengan demikian persamaan regresi temuan di atas adalah persamaan regresi berganda dengan model $\stackrel{\mathrm{Y}}{=}=6,462+0,656 \mathrm{X}_{1}+0,229 \mathrm{X}_{2}$

Hasil penelitian juga menunjukkan bahwa terdapat pengaruh yang signifikan peranan orang tua dan pola asuh orang tua secara bersama-sama (simultan) terhadap Hasil Belajar PKn siswa, sebagaimana Tabel 2.

Tabel 2. Anova Pengaruh Peranan dan Pola Asuh Orang Tua Terhadap Hasil Belajar

\begin{tabular}{llrrrrc}
\multicolumn{7}{c}{ ANOVA $^{\text {a }}$} \\
\hline Model & & Sum of Squares & \multicolumn{1}{c}{$d f$} & Mean Square & \multicolumn{1}{c}{ S } & Sig. \\
\hline \multirow{2}{*}{1} & Regression & 2065.959 & 2 & 1032.979 & 192,634 & $0,000^{\circ}$ \\
& Residual & 520.151 & 97 & 5.362 & & \\
\cline { 2 - 7 } & Total & 2586.110 & 99 & & & \\
\hline
\end{tabular}

a. Dependent Variable: Hasil Belajar Siswa

b. Predictors: (Constant), Pola Asuh Orang Tua, Peranan Orang Tua 
Nilai F sebesar 192,634 dan tingkat signifikansi 0,000 < 0,05 menunjukkan pengaruh simultan yang signifikan antara peranan orang tua dan pola asuh terhadap hasil belajar siswa.

Tabel 3. Kontribusi Peranan Orang Tua dan Pola Asuh Secara Simultan Terhadap Hasil Belajar

\begin{tabular}{ccccc}
\hline Model & $R$ & $R$ Square & Adjusted $R$ Square & $\begin{array}{c}\text { Std. Error of the } \\
\text { Estimate }\end{array}$ \\
\hline 1 & $0,894^{a}$ & 0,799 & 0,795 & 2,316 \\
\hline
\end{tabular}

a. Predictors: (Constant), Pola Asuh Orang Tua, Peranan Orang Tua

Koefisien Determinasi (KD) secara simultan (Tabel 3) menunjukkan nilai R Square 0,799, artinya peranan orang tua dan pola asuh orang tua memberikan kontribusi sebesar 79,9\% terhadap Hasil Belajar PKn siswa, sedangkan 20,1\% hasil belajar PKn siswa dipengaruhi oleh variabelvariabel lain yang tidak diteliti dalam penelitian ini.

Ketika anak memasuki dunia pendidikan yang disebut dengan sekolah dasar, tentu aktivitasaktivitas yang dilakukan anak pun mengalami perubahan dan pergeseran. Sewaktu belum bersekolah, mungkin aktivitas anak banyak di rumah bersama orang tua ataupun bermain dengan teman sebayanya. Namun, ketika bersekolah aktivitas anak bertambah seiring tuntutan dari program sekolah itusendiri.

Hal utama yang harus dipelajari anak ketika masuk sekolah dasar adalah calistung (baca, tulis, hitung), kemudian berkembang menjadi beberapa pokok bahasan dalam ilmu pengetahuan tertentu. Dalam hal ini tentu orang tua mengharapkan anaknya untuk mampu menguasai kompetensi yang distandarkan oleh kurikulum. Namun orang tua tidak boleh salah menafsirkan, bahwa anakanak yang sudah masuk sekolah menjadi tanggung jawab sekolah sepenuhnya.

Orang tua masih harus tetap berpartisipasi terhadap pendidikan anak. Sebagai orang tua yang baik, pendidikan merupakan bekal untuk anak dimasa depan. Namun dunia anak bukan hanya untuk belajar. Jika anak hanya disuruh belajar dan belajar tanpa ada aktivitas yang lain tentu hal ini akan membuat jenuh seorang anak. Anak-anak memerlukan aktivitas yang lain seperti istirahat, olahraga, dan bermain. Untuk itu para orang tua dapat bekerja sama mengatur waktu atau jadwal kegiatan anak. Adapun cara untuk membuat jadwal yang baik sebagaimana yang diungkapkan oleh Slameto (2010:82) adalah sebagai berikut:

a. Memperhitungkan waktu setiap hari untuk keperluan tidur, belajar, makan, mandi, olahraga, bermain, dan lain-lain.

b. Menyelidiki dan menentukan waktu-waktu yang tersedia setiap hari.

c. Merencanakan penggunaan belajar itu dengan cara menetapkan jenis-jenismata pelajarannya dan urutan-urutan yang harus dipelajari.

d. Menyelidiki waktu-waktu mana yang dapat dipergunakan untuk belajar dengan hasil terbaik. Sesudah waktu itu diketahui, kemudian pergunakan untuk mempelajari pelajaran yang dianggap sulit. Pelajaran yang dianggap mudah dipelajari pada jam lain.

e. Berhematlah dengan waktu, setiap siswa janganlah ragu-ragu untuk memulai pekerjaan termasuk belajar.

Orang tua selalu mempunyai pengaruh yang paling kuat pada anak-anak. Setiap orang tua mempunyai gaya tersendiri dalam hubungannya dengan anak-anaknya, dan ini mempengaruhi perkembangan sosial anak. Pola asuh yang berbeda-beda berkaitan erat dengan sifat kepribadian 
yang berbeda-beda pada setiap anak. Hurlock (2004: 94) menyebutkan bahwa pola asuh dibagi menjadi tiga tipe yang dikenal dengan pola asuh otoriter, pola asuh demokratis dan pola asuh permisif.

Pola asuh orang tua yaitu pola pengasuhan orang tua terhadap anak, yaitu bagaimana orang tua memperlakukan anak, mendidik, membimbing dan mendisiplinkan serta melindungi anak dalam mencapai proses kedewasaan sampai dengan membentuk perilaku anak sesuai dengan norma dan nilai yang baik dan sesuai dengan kehidupan masyarakat. Pola asuh orang tua dengan dua dimensi, diantaranya: (1) dimensi tuntutan atau demandingness, dengan indikator: (a) memberikan batasan terhadap aktivitas anak, (b) menuntut sikap tanggung jawab anak, (c) memberikan peraturan yang harus ditaati oleh anak, (d) terlibat dalam kehidupan anak, dan (e) memberikan ganjaran secara continue. (2) Dimensi tanggapan atau responsiveness, dengan indikator: (a) perhatian terhadap anak, (b) respon terhadap kebutuhan anak, (c) meluangkan waktu dan melakukan kegiatan bersama anak, (d) kepekaan terhadap emosi anak, dan (e) memberikan penghargaan terhadap prestasi dan perilaku positif anak.

Peran orangtua sangat penting dalam mewujudkan keberhasilan pendidikan buah hatinya. Namun, masih banyak orangtua yang kurang menyadari akan perannya dalam mendukung pendidikan anak dan menyerahkan sepenuhnya pada sekolah. Sayangnya, tak banyak orangtua menyadari bahwa perannya dalam mendukung pendidikan anak sangat mempengaruhi keberhasilan anak dalam belajar dan bersosialisasi.

Banyak yang menyerahkan pendidikan anak sepenuhnya kepada pihak sekolah.untuk dapat mewujudkan keberhasilan pendidikan, dibutuhkan sinergi yang harmonis antara pihak sekolah dan orangtua. Lingkungan keluarga dalam hal ini orangtua memiliki peran yang sangat besar serta merupakan komunitas yang paling efektif untuk membina seorang anak agar berprestasi baik. Di sinilah seharusnya orangtua mencurahkan rasa kasih sayang dan perhatian kepada anaknya untuk mendapatkan bimbingan rohani yang jauh lebih penting dari sekedar materi. Seandainya dalam lingkungan keluarga sudah tercipta suasana yang harmonis.

\section{SIMPULAN}

Berdasarkan hasil analisis data dan uraian hasil penelitian yang dikemukakan di atas dapat disimpulkan bahwa terdapat pengaruh positif dan signifikan peranan orang tua terhadap hasil belajar PKn siswa. Pola asuh orang tua atau pola pengasuhan dari orang tua terhadap anak ternyata juga mempunyai pengaruh positif dan signifikan terhadap hasil belajar siswa. Terdapat pengaruh positif dan sangat signifikan peranan orang tua $\left(X_{1}\right)$ dan pola asuh orang tua $\left(X_{2}\right)$ secara bersama-sama terhadap hasil belajar PKn siswa $(Y)$. Ini berarti bahwa semakin baik peranan orang tua dan pola pengasuhan orang tua maka akan makin tinggi pula hasil belajar siswa.

Sebagai implikasi dari temuan penelilitan ini, guru diharapkan dapat menjalin komunikasi dengan orang tua dalam hal mendiskusikan jadwal kegiatan sehari-hari anak, menjalin komunikasi dengan anak mengenai belajar anak, menyiapkan sarana belajar anak, menciptakan suasana belajar yang nyaman bagi anak, mengizinkan dan mengatur waktu bermain bagi anak, sebagai perwujudan dari peranan orang tua dalam proses belajar anak. Di samping itu dalam pengasuhan anak orang tua perlu untuk memberikan batasan terhadap aktivitas anak, menuntut sikap tanggung jawab anak, memberikan peraturan yang harus ditaati oleh anak, terlibat dalam kehidupan anak, perhatian terhadap anak, respon terhadap kebutuhan anak, meluangkan waktu serta melakukan kegiatan bersama anak, dan peka terhadap emosi anak. 


\section{REFERENSI}

Ahmadi, A. \& Uhbiyati, N. (2007). Ilmu Pendidikan. Jakarta: PT Rineka Cipta.

Anwar, Saifuddin. (2005). Metode Penelitian. Yogyakarta: Pustaka Pelajar Offset.

Asmara. (2009). Prestasi Belajar. Bandung.PT. Remaja Rosdakarya.

Atmosiswoyo, Subyakto, \& Subyakto Harmiwati. (2002). Peran Keluarga: Anak. Unggul Berotak

Prima. Jakarta: Gramedia Pustaka Utama.

Casmini. (2007). Emotional Parenting. Yogyakarta: Nuansa Aksara.

Chasiyah, Chadidjah, \& Legowo, Edy. (2009). Perkembangan Peserta Didik. Surakarta: Yuma Pustaka.

Djamarah, Saiful Bahri. \& Zain, Aswan. (2002). Strategi Belajar Mengajar. Jakarta: Rineka Cipta.

Faizi, Mastur. (2012). Tiru Cara-Cara Ampuh Mendidik Anak Ala Pendidikan Orang Hebat. Jogyakarta: Flashbooks.

Hadi, Soedomo. (2003). Pendidikan Suatu Pengantar. Surakarta: Sebelas Maret University Press.

Hamalik, Oemar. (2008). Kurikulum Dan Pembelajaran. Jakarta: Bumi Aksara.

Hurlock, Elizabeth B. (2004). Perkembangan Anak Jilid 2: Edisi Ke Enam. Jakarta: Erlangga.

Iryanto. (2000). Pendidikan Dalam Keluarga, Jakarta: Bulan Bintang.

Lestari, Sri. (2012). Psikologi Keluarga. Jakarta: Kencana Preanada Media Group.

Purwanto, M. Ngalim. (2002). Prinsip-prinsip Dan Teknik Evaluasi Pengajaran. Bandung: Remaja Rosdakarya.

Singgih, G. (2007). Psikologi Perkembangan. Jakarta: Gunung Mulia.

Slameto. (2010). Belajar Dan Faktor-Faktor Yang Mempengaruhinya. Jakarta: Rineka Cipta.

Slicker, Ellen K, Billie K. Picklesimer, Andrea K. Guzak, \& Dana K Fuller. (2005). The Relationship Of Parenting Style To Older Adolescent Life-Skills Development In The United States.

UU RI No.20 Tahun 2003. Sistem Pendidikan Nasional. Bandung: Citra Umbara. 